\title{
Perceptions of Pre-Service Teachers on Student Burnout, Occupational Anxiety and Faculty Life Quality
}

\author{
Muhammet Emin Türkoğlu ${ }^{1} \&$ Ramazan Cansoy ${ }^{2}$ \\ ${ }^{1}$ Ahmet Necdet Sezer Campus, Faculty of Education, Afyon Kocatepe University, Afyonkarahisar, Turkey \\ ${ }^{2}$ Department of Educational Sciences, Faculty of Letters, Karabük University, Karabuk, Turkey \\ Correspondence: Muhammet Emin Türkoğlu, Ahmet Necdet Sezer Campus, Faculty of Education, Afyon \\ Kocatepe University, Afyonkarahisar, Turkey. E-mail: eminturkoglu@gmail.com
}

Received: July 26, 2017

Accepted: August 8, 2017

Online Published: August 10, 2017

doi:10.5539/jel.v6n4p315

URL: http://doi.org/10.5539/jel.v6n4p315

\begin{abstract}
Perceptions of pre-service teachers on burnout, occupational anxiety and faculty life quality were investigated in this research. The research group consisted of 461 pre-service teachers in total studying at Afyon Kocatepe University faculty of education. "Maslach Burnout Inventory-Student Form", "Faculty Life Quality Scale" and "Occupational Anxiety Scale for Pre-Service Teachers" were used in the collection of the research data. The information on the demographic features of the participants was collected as gender, age, branch and division. Arithmetic mean and T-test were used in the analysis of the data. In the research, it was seen that the burnout levels of pre-service teachers are at moderate level, and they are centred the dimension of feeling competent. It was found that occupational anxiety is centred in appointment related anxiety. It was seen that the level of satisfaction on the quality of faculty life is at a moderate level and it is centred on the dimension of satisfaction with the teaching staff. It was found that the faculty life quality satisfaction levels of female pre-service teachers are higher than male pre-service teachers. On the other hand, the burnout and occupational anxiety levels of female pre-service teachers were found significantly higher than male pre-service teachers.
\end{abstract}

Keywords: student burnout, teaching profession anxiety, faculty life quality

\section{Introduction}

The intense education that students receive at the faculty of education and their starting to study for KPSS [Public Personnel Selection Exam] further increase their load. First-year appointment rates of the students graduated from education faculties are quite low. These appointment rates vary between $.62 \%$ and $28.89 \%$ by branches (Mebpersonel.com). In addition to this, it is known that the number of pre-service teachers at faculties of education is much higher than the current need (Özoğlu, 2010). Starting from these results, it can be expressed that pre-service teachers will be exposed to intense pressure about whether they will be appointed when they graduate in the years when they are students. Reducing these pressures may be regarded among the important duties of universities. In this context, it is seen in recent years that the burnout, occupational anxiety and faculty life quality of university students have been the subject of some research (e.g., Gündüz, Çapri, \& Gökçakan, 2012; Cabı \& Yalçınalp, 2013; Gözler, Bozgeyikli, \& Avc1, 2017; Özdemir, Kılınç, Öğdem, \& Er, 2013). These studies were conducted on the students studying at different departments of universities. With this study, it is aimed to expand the literature at the faculty of education. Hence, certain findings can be provided on determining and improving the areas where the occupational anxiety, burnout and levels of satisfaction with the faculty of the students from the faculty of education are found inadequate can be revealed.

\subsection{Occupational Anxiety}

Anxiety can be explained as the discomfort and tension that one feels about a perceived threat (Schwarzer, 2013). Anxiety is frequently investigated primarily in the science of psychology. However, it is also an important subject that is also investigated in the field of education due to the negativities encountered in school life (Gözler, Bozgeyikli, \& Avc1, 2017). The level of anxiety of an individual is more important than being anxious. Individuals with high anxiety exhibit more different attitudes than they normally do. On the contrary, anxiety at lower levels plays a key role in activating an individual, increasing the efficiency and protecting oneself (Akgün, Gönen, \& Aydın, 2007). 
There are certain factors that may reveal the occupational anxiety of pre-service teachers at faculties of education. And KPSS (Public Personnel Selection Exam) applied for being a teacher is at the top of these. The exam triggers anxiety and hopelessness for the future in the students (Tümkaya, Aybek, \& Çelik, 2007). In Turkish Education System, graduation from a university does not guarantee to become a teacher for pre-service teachers. It is necessary to take KPSS, which is a nation-wide exam, to be appointed (Doğan \& Çoban, 2009). According to the scores taken from KPSS exam, a second stage that waits for the pre-service teachers is to obtain the necessary base score for the limited number of teacher quota. At the present time, where the number of the pre-service teachers that rapidly increases, there are other reasons that increase this number. With a decision taken by the Higher Education Authority (YÖK), students studying at the Faculties of Science and Letters were also entitled to become teachers by giving them pedagogical formation training (Özoğlu, 2010). On the other hand, pre-service teachers receive formation lessons both on the branch they study and teaching profession. Nevertheless, pre-service teachers are not provided guidance on the situations they may encounter after graduating from the university. It can be considered that this uncertainty constitutes the basis of their anxiety regarding practising one's profession (Dursun \& Karagün, 2012). Therefore, pre-service teachers do not know whether they will work as teachers after they graduate (Doğan, Sarı, Kazak, Saya, \& Altıntaş, 2007). This causes certain anxieties about the future of pre-service teachers such as getting a job, financial difficulties, professional respectability and acceptance (Cabı \& Yalçıalp, 2009). Consequently, it is necessary to perform guidance activities for pre-service teachers to eliminate the uncertainties about their future life and also state policisies on this should be revised.

Cabı and Yalçınalp (2013) approach occupational anxiety as an 8-dimensional structure: (i) task-centred anxiety, (ii) economic/social centred anxiety, (iii) student/communication centred anxiety, (iv) colleague and parent centred anxiety, (v) personal development centred anxiety, (vi) appointment centred anxiety, (vii) adaptation centred anxiety, (viii) school management centred anxiety. According to Cabi and Yalçınalp (2013), these anxieties are gathered into 3 main categories: Self-centred anxieties, student-centered anxieties and task-centred anxieties. Self-centered anxieties personally concern the pre-service teachers. There are anxieties related to communication with the student in the centre of student-centered anxieties. And the anxiety of whether the tasks related to the profession is in the centre of task-centred anxieties.

\subsection{Burnout}

Burnout stands out as a negative concept that reduces efficiency in different profession groups and persons from 1970s to today (Maslach, Schaufeli, \& Leiter, 2001). Burnout is the physical, emotional and mental straining of an individual above the limits that he/she can bear (Pines \& Aronson, 1988). In other words, it explains a process that leads to the weakening of the job-related expectations, desensitisation and inadequacies in the skills related to the work in general as a result of the negative emotions one feels regarding one's job (Maslach \& Leiter, 1997). In summary, burnout is a situation that decreases productivity in individuals, reduces efficiency, and consequently causes negative emotions in individuals (Maslach, 2001; Schaufeli \& Bakker, 2004).

There are certain reasons that lead to burnout. The place where a person lives brings about excessive physical and emotional exhaustion, and consequently burnout (Freudenberger, 1974). There are striking findings on the term burnout in the area of educational. The group that stands out in the researches related to the term burnout in recent years is university students (Cakir, 2015; Frisby, Goodboy, \& Buckner, 2015; Goodboy, Martin, \& Johnson, 2015; Galbraith \& Merrill, 2015; Hojat, Vergare, Isenberg, Cohen, \& Spandorfer, 2015; Stoliker \& Lafreniere, 2015; Jackson, Shanafelt, Hasan, Satele, \& Dyrbye, 2016; Kocaeksi, 2016). In the studies regarding the burnout of university students, it is seen that burnout affects the learning of the students negatively (Gündüz, Çapri, \& Gökçakan, 2012).

Schaufeli, Martinez, Marques-Pinto, Salanova and Bakker (2002) investigate burnout as a three-dimensional structure: (i) Burnout, (ii) Desensitisation, and (iii) the sense of competency. Burnout is a phenomenon that negatively affects a student both physically and psychologically, and reduces the student's interest in education. Desensitisation is an attitude that causes the loss of interest and decisiveness of students in their studies at the university. Whereas the sense of competency is that a student feels that he/she is at sufficient level in solving the problems, participating in the lessons and determining the targets.

\subsection{Faculty Life Quality}

Most time of the students' lives are spent at schools, and the teaching outputs are expected to be qualified (Özdemir, 2012). The realisation of such an expectation is naturally closely related to the quality of the education received by the students that they love the school and the teachers, and their general school lives. The school life quality conceptualised by Epstein and McPartland (1976) can be defined as the general satisfaction of students 
with the school, their commitment to the school and their attitudes towards their teachers. According to Karatzias et al. (2002), school life quality is a general state of happiness that students feel as a result of their involvement in school life and around it. And according to Thien and Razak (2013), school life quality is a synthesis of positive or negative experiences at school. A high-quality school life has many positive effects, primarily academic success. On the other hand, negative perceptions on school life may lead to negative effects that may reach up to drop outs (Ayık \& Ataş-Akdemir, 2016). Just as in different education levels, the life quality and satisfaction of students are important (Erimez \& Gizir, 2013). Young people with different expectations from different circles may have negative emotions and prejudices. Epstein and McPartland (1976) investigates school life quality in 3 dimensions: (i) general school satisfaction, (ii) classroom works of the students, and (iii) the reactions of students towards teachers. The faculty life quality scale used in the research also consists of 3 dimensions: (i) satisfaction with the faculty, (ii) satisfaction with the teaching staff, (iii) satisfaction with the classroom environment and student relationships. The satisfaction with the faculty represents a wide framework that covers socio-cultural facilities, physical opportunities and the student's commitment to the school. The satisfaction with the teaching staff is generally a structure that explains the personal qualities of the teaching staff, and the cooperation and communication between teachers and students. And satisfaction with the classroom environment and student relationships includes the quality of the education in classroom and friendship relationships (Çokluk Bökeoğlu \& Yılmaz, 2007).

Students have different expectations at universities that are rapidly increasing in number, and in faculties of education opened in parallel with this. It is necessary to understand the level that these expectations of the students are fulfilled both in years that they received training and thereafter, and taking the expectations of the students into consideration. The extent that the training provided in education faculties, occupational anxieties, burnout and faculty satisfaction of pre-service teachers who will raise the future generations should constantly be questioned. In this context, the following research questions were investigated in this research.

1) According to the perceptions of the students of the faculty of education, how are the burnout level, anxieties on the teaching profession, and satisfaction of the students with the faculty life quality?

2) According to the perceptions of the students of the faculty of education, do the burnout level, anxieties on the teaching profession, and satisfaction of the students with the faculty life quality vary by gender?

\section{Method}

In this section research design, participants, instruments and data analysis are explained.

\subsection{Research Design}

This research was prepared in screening model. Burnout levels, anxieties towards teaching profession and satisfaction levels with the faculty life of pre-service teachers are investigated in the research.

\subsection{Participants}

The study group of the research consists of 461 pre-service teachers in total, studying at at a faculty of education in the Eagean region of Turkey. The age average of the candidates is $21.8 .352(76 \%)$ of the participants are female, and $109(24 \%)$ are male. 134 (29\%) of the participants are third grade, and $327(71 \%)$ are fourth-grade students. In the research, the sample was chosen from easily accessible and implementable units due to certain limitations regarding time, money and labour force.

\subsection{Instruments}

The information on the demographic features of the participants was collected as gender, age, branch and department. Maslach Burnout Inventory-Student Form, Occupational Anxiety Scale for Pre-Service Teachers and the Scale of Faculty Life were used in the study to collect data.

\subsubsection{Faculty Life Quality Scale}

The scale was developed by Epstein and Mcpartland (1976), and it was adapted into Turkish culture by Y1lmaz and Çokluk-Bökeoğlu (2006). The scale consists of 15 items regarding the satisfaction with the faculty, 15 items regarding the satisfaction with teaching staff, and 7 items regarding the classroom environment and student relationships. The variance that explains the satisfaction with the faculty dimension is $23 \%$, the satisfaction with the teaching staff is $31 \%$, and the satisfaction with student relationships is $34 \%$, respectively. Cronbach's Alpha numbers calculated on the reliability of these sub-dimensions vary between .67 and .83 . And the Cronbach's alpha reliability coefficient calculated for the whole scale is .87. The scale was prepared in 5-item Likert type graded between "(1) Totally disagree" and "(5) Totally agree". Example items for the dimension of satisfaction with the faculty "I am happy with being a member of this faculty", "The discipline policies applied by the 
management of the faculty are consistent"; example items for (ii) the dimension of satisfaction with the teaching staff are "The teaching staff at the faculty supports me in the studies that I am interested in"; example items for (iii) The classroom environment and student relationships are in the form of "Good friends are made in this faculty", "Students in this faculty can comfortably express their opinions" (Yılmaz \& Bökeoğlu, 2006). Cronbach's Alpha coefficients calculated for the reliability of the present work was found as .76 for the dimension of satisfaction with the faculty, .88 for the dimension of satisfaction with the teaching staff, and .69 for the dimension of satisfaction with the classroom environment and student relationships. Cronbach's Alpha reliability value calculated for the whole scale is .91 .

\subsubsection{Maslach Burnout Inventory-Student Form}

The scale was developed by Schaufeli, Martinez, Marques-Pinto, Salanova and Bakker (2002); and it was adapted into Turkish culture by Çapri, Gündüz and Gökçakan (2011). The dimensions, item numbers and example items are as follows: The scale consists of 3 dimensions and 13 items. The dimensions of the scale are burnout, desensitisation and competence. Burnout dimension consists of 5 items, desensitisation dimension consists of 4 items, and academic competence dimension consists of 4 items. Sub-scales are scored and evaluated separately. High scores taken from burnout and desensitisation sub-factors and low scores taken from competence sub-factor show that there is burnout. The scale was prepared in 5-item Likert type between the interval "(1) Never" and "(5) Always". Cronbach's Alpha values calculated for reliability were found as .76 for the Burnout dimension, .82 for desensitisation dimension, and .61 for competence dimension. The scale was applied confirmatory factor analysis, and it was stated that the three-factor structure shows good compliance. It is stated that the factor loads in the scale vary between .41 and .83 . It was seen that the correlation values between the dimensions vary between .32 and .83 , and the criterion validity of the scale was also ensured. Example items are as follows: Burnout "I feel that I am breaking down emotionally in my lessons", Desensitization "My interest in the lessons decreased after I started the training", the Sense of Competence "I can solve the problems I encounter in my lessons appropriately" (Çapri, Gündüz, \& Gökçakan, 2011). In the present study, the scale is expressed with a 10-item grading between "(1) Never" and "(10) Always". The internal consistency coefficient calculated for testing the reliability of the scale in the present study was found as .63 for burnout, .69 for desensitisation, .53 for competence, and the reliability value of the whole scale was found as .78. The items of the competence dimension were reverse scored in the present study, and the naming was expressed as not feeling competent.

\subsubsection{Occupational Anxiety Scale for Pre-Service Teachers}

The scale was developed by Cabı and Yalçınalp (2013). It consists of 45 items and 8 sub-dimensions. The Likert type scale was prepared with 5-item grading from "(1) I do not worry" and "(5) I definitely worry". The scale contains 14 items for task-centred anxiety, 7 items for economic/social based anxiety, 6 items for student/communication centred anxiety, 5 items for colleague and parent centred anxiety, 4 items for personal development centred anxiety, 3 items for appointment centred anxiety, 3 items for compliance centred anxiety, and 3 items for school management centred anxiety. The total variance explained by the scale is $65.72 \%$. And it is seen that Cronbach's Alpha values calculated for the reliability of the sub-dimensions vary between .67 and .94. And the reliability value of the whole scale was found as .95. Example items are as follows: "I do not worry about not ensuring the authority in the classroom/I definitely worry", "I am not worried about not being respected by my students/I definitely worry" (Cabı \& Yalçınalp, 2013). It was seen that the Cronbach's Alpha value calculated for reliability in the present study varies between .58 and .91 , and it is .95 for the whole scale.

\subsection{Data Analysis}

SPSS program was used in the analysis of the data. Upon investigated the skewness and kurtosis values on the normality of the data, it was seen that the skewness and kurtosis data are between $(-1)$ and $(+1)$ and varies between (-.32) and (.42). For a normal distribution, Q-Q graph was also examined. It was assumed that the data vary normally. The arithmetic mean of the burnout inventory sub-dimension scores, and the scores obtained from the Occupational Anxiety Scale for Pre-Service Teachers and Faculty Life Quality Scale were calculated for the analysis of the data obtained for the solution of the sub-problems in the research. The analyses were made using these values. The significance of the data was decided by the level .05 .

\section{Results}

This section contains average and standard deviation values on the perceptions of the students regarding burnout, occupational anxieties and faculty life quality. 


\subsection{Avarage and Standart Deviation Values}

In Table 1, average and standart deviation values on the burnout, occupational anxieties and faculty life quality are presented.

Table 1. Average and standard deviation values on the burnout, occupational anxieties and faculty life quality

\begin{tabular}{lll}
\hline Variables & $\bar{X}$ & $\mathbf{S}$ \\
\hline 1. Satisfaction with the faculty & 2.99 & .51 \\
2. Satisfaction with the teaching staff & 3.30 & .68 \\
3. Satisfaction with the classroom environment and student relationships & 3.17 & .64 \\
Faculty life quality [Whole Scale] & $\mathbf{3 . 1 5}$ & $\mathbf{. 5 3}$ \\
4. Burnout & 4.20 & 1.95 \\
5. Desensitization & 4.38 & 2.09 \\
6. Not feeling competent & 5.04 & 1.90 \\
Burnout [Whole Scale] & $\mathbf{4 . 5 4}$ & $\mathbf{1 . 1 0}$ \\
7. Task-centred anxiety & 2.33 & .82 \\
8. Economic/social-centred anxiety & 2.62 & .87 \\
9. Student/communication-centred anxiety & 2.37 & .91 \\
10. Colleague and parent-centred anxiety & 2.25 & .80 \\
11. Personal development-centred anxiety & 2.40 & 1.11 \\
12. Appointment-centred anxiety & 3.21 & .93 \\
13. Compliance-centred anxiety & 2.50 & 1.06 \\
14. School management-centred anxiety & 2.47 & .86 \\
Occupational Anxiety [Whole Scale] & $\mathbf{2 . 4 5}$ & $\mathbf{. 6 7}$ \\
\hline
\end{tabular}

Upon investigating Table 1, it is seen that the perceptions of pre-service teachers on the faculty life quality are at a medium level $(\bar{X}=3.15)$, burnout levels are at a medium level $(\bar{X}=4.54)$, and their anxiety on teaching profession is close to medium level $(\overline{\mathrm{X}}=2.45)$. It is seen that the lowest perceived dimension on faculty life quality is the satisfaction of the faculty $(\bar{X}=2.99)$. As for student burnout, it is seen that the highest level burnout intensifies in the burnout $(\overline{\mathrm{X}}=4.20)$ dimension. In occupational anxiety dimension, it is seen that the highest levels of anxiety concentrate in appointment centred $(\overline{\mathrm{X}}=3.21)$ and economic/social-centred anxiety $(\overline{\mathrm{X}}=2.62)$.

\subsection{T-Test Results}

The results of T-test by gender are presented in Table 2 .

Table 2. T-test results by gender on the burnout, occupational anxiety and faculty life quality of the students

\begin{tabular}{lllllllll}
\hline & Group & $\mathrm{n}$ & $\overline{\mathrm{X}}$ & $\mathrm{ss}$ & $\mathrm{sd}$ & $\mathrm{t}$ & $\mathrm{df}$ & $\mathrm{p}$ \\
\hline Satisfaction with the faculty life quality & Female & 352 & 3.19 & .52 & .03 & & \\
& Male & 109 & 3.04 & .57 & .05 & 2.67 & 459 & .008 \\
\multirow{3}{*}{ Student Burnout } & Female & 352 & 4.52 & 1.08 & .06 & & \\
& Male & 109 & 4.63 & 1.16 & .11 & -.90 & 459 & .367 \\
Occupational anxiety for teaching & Female & 352 & 2.52 & .67 & .04 & & .06 & .001 \\
\hline
\end{tabular}


According to Table 2, it is seen that the faculty life satisfaction perceptions of female students are higher than male students by gender, and this difference is statistically significant $(p<.05)$. When we look at Table 2 , we see that the average occupational anxiety of female students is higher than male students by gender, and this difference is statistically significant $(p<.05)$. There is no significant difference between female and male students in terms of student burnout $(p>.05)$.

\section{Discussion}

Burnout levels of pre-service teachers were investigated in the research. Burnout levels of pre-service teachers were found at a medium level. It is seen that the burnout of pre-service teachers concentrates in the dimension of not feeling competent, and this dimension is followed by desensitisation and burnout. Not feeling competent is the dimension where pre-service teachers are at the highest level. There are studies that are similar to this finding (Kocaekşi, 2016; Kaya \& Ariöz, 2014). That not feeling competent is at a higher level than the other dimensions can be considered as a negative result. As the students are at a medium level in terms of burnout and desensitisation in this study, it can be considered that it is correlated with their perceiving their own competence at a low level. Excessive physical and emotional exhaustion of individuals depending on the environments they live brings together burnout (Freudenberger, 1974). It is seen that burnout affects the learning of the students negatively (Gündüz, Çapri, \& Gökçakan, 2012). The intensity of the exams at the faculties of education, uncertainties in the future, and that becoming a teacher and being appointed get gradually harder may be among the reasons for this situation. That the burnout in students is at medium level can be considered as a negative result. In this sense, conducting studies on the reasons that lead to burnout can be suggested. And faculty management should often take measures related to burnout, which is a major hurdle in the learning of students. The provision of more counseling services by lecturers and a genuine relationship with the students can help solve this problem.

Occupational anxiety levels of pre-service teachers in the teaching profession were investigated in the research. It is seen that the features that are worried about at the highest level in the occupational anxiety dimension concentrate in appointment centred anxiety. Findings in different studies support the findings of the research (Dursun \& Karagün, 2012; Tümkaya, Aybek, \& Çelik, 2007; Özoğlu, 2010). Appointment-centred anxiety is at a much higher level than other anxieties. This shows that there is significant uncertainty about whether students will practise the teaching profession in the future. It is necessary for policy-makers to make serious planning about teacher employment, and a balance should be established between the number of the pre-service teachers graduated and the teachers who are appointed. It can be stated that this causes serious hopelessness beyond anxiety. Taking more students from branches with a higher rate of appointment to faculties can be considered as a solution to this. On the other hand branches with low levels of appointment should be considered carefully before taking students.

The satisfaction levels of pre-service teachers from faculty life were investigated in the research. Research findings show that the perceptions of students on faculty life quality are at medium level. It is seen that the lowest level of perceived dimension is faculty life quality, while the dimension perceived at the most adequate level is the satisfaction with the teaching staff. There are findings that are similar to this finding (Aylk \& Ataş-Akdemir, 2015). A high-quality school life has many positive effects, and mainly an academic success. On the other hand, negative perceptions on faculty life lead to negative effects that may reach up to dropping out. Different studies conducted show that the communication between the teachers and students have a vital importance. This finding of the research matches the research results (Yllmaz, 2007; Argon \& Kösterelioğlu, 2009; Kalaycı \& Özdemir, 2013). Accordingly, it can be said that the quality of the teaching staff and their attitudes towards the students are the most important factors that ensure faculty satisfaction. It can be considered as a proposal to increase the social activities in the school.

In the research, it is seen that the occupational anxiety of female students is higher than male students, and this difference is statistically significant. Upon investigating different studies carried out on the subject, it is also seen that female students are more anxious than male students (Bozkurt, 2004; Dursun \& Karagün, 2012; Rosenthal \& Schreiner, 2000; Çakmak \& Hevedanl1, 2005; Tabancalı, Çelik, \& Korumaz, 2016). There is no statistically significant difference between female and male students in terms of the burnout of pre-service teachers in the research. The studies in the literature also show there is no significant difference in terms of the gender variable related to burnout, and this is similar to the research results (Dolunay, 2002; Kırılmaz, Çelen, \& Sarp, 2003; Kocaekşi, 2016). Whether the faculty life quality scores of pre-service teachers vary significantly by gender was investigated in the research. According to the research results, findings point out that the school life quality perceptions of female pre-service teachers are significantly higher than male pre-service teachers. This finding 
matches the results of different studies (Dost, 2007; Özdemir, 2012; Cenkseven \& Akbaş, 2016). In this context, it can be suggested that researches are carried out at faculties on the reasons for burnout, and occupational anxiety in female pre-service teachers and remedial work is carried out according to their results.

According to research results, it may be suggested that universities focus on individual guidance at universities for reducing the burnout and occupational anxieties of pre-service teachers. In addition to this, coaching and mentoring services that will ensure that students get to know and guide their own emotions can be conducted as of the first years. It may be tried to improve the physical conditions on increasing the level of satisfaction of students from their faculties. In addition to this, social and cultural activities can be increased. It can be suggested that faculty members and students do activities together in order to increase the commitment of students to their faculties. Universities are strategic institutions where information is produced (Bonaccorsi \& Daraio, 2007) and individuals can reveal their existing potentials (Deiaco, Hughes, \& McKelvey, 2012). Therefore, the conditions of these institutions should be improved, and practices on the self-discovery of the individuals should be implemented.

\section{References}

Akgün, A., Gönen, S., \& Aydın, M. (2007). İlköğretim fen ve matematik öğretmenliği öğrencilerinin kayg1 düzeylerinin bazı değişkenlere göre incelenmesi. Elektronik Sosyal Bilimler Dergisi, 6(20), 283-299.

Argon, T., \& Kösterelioğlu, M. A. (2009). Üniversite öğrencilerinin üniversite yaşam kalitesi ve fakülte kültürüne ilişkin algıları. Electronic Journal of Social Sciences, 8(30), 43-61.

Ayık, A., \& Ataş-Akdemir, Ö. (2015). Öğretmen adaylarının okul yaşam kalitesi ve okula yabancılaşma algıları arasındaki ilişki. Kuram ve Uygulamada Eğitim Yönetimi Dergisi, 21(4), 429-452.

Bonaccorsi, A., \& Daraio, C. (2007). Universities as strategic knowledge creators: Some preliminary evidence. Universities and strategic knowledge creation. In A. Bonaccorsi, \& C. Daraio (Eds.), Universities and strategic knowledge creators (pp. 31-81). Great Britain: MPG Books Limited. https://doi.org/10.4337/9781847206848

Bozkurt, N. (2004). Bir grup üniversite öğrencisinin depresyon ve kaygı düzeyleri ile çeşitli değişkenler arasındaki ilişkiler. Eğitim ve Bilim, 29(133), 52-59.

Cabı, E., \& Yalçınalp S. (2009). Öğretmen adaylarının mesleki ve eğitim teknolojilerini kullanma kaygı düzeylerine yönelik görüş̧leri, IV. International Educational Technology Conference.

Cabı, E., \& Yalçınalp, S. (2013). Öğretmen adaylarına yönelik mesleki kaygı ölçeği (MKÖ): Geçerlik ve güvenirlik çalışması. Hacettepe Üniversitesi Eğitim Fakültesi Dergisi, 44, 85-96.

Cakir, S. G. (2015). The effects of teacher immediacy and student burnout on empowerment and resistance among Turkish pre-service teachers. Learning and Individual Differences, 40(2015), 170-175. https://doi.org/10.1016/j.lindif.2015.05.002

Cenkseven, F., \& Akbaş, T. (2016). Üniversite öğrencilerinde öznel ve psikolojik iyi olmanın yordayıcılarının incelenmesi. Türk Psikolojik Danışma ve Rehberlik Dergisi, 3(27), 43-65.

Çakmak, Ö., \& Hevedanlı, M. (2005). Eğitim ve fen edebiyat fakülteleri biyoloji bölümü öğrencilerinin kaygı düzeylerinin çeşitli değişkenler açısından incelenmesi. Elektronik Sosyal Bilimler Dergisi, 4(14), 115-127.

Çapri, B., Gündüz, B., \& Gökçakan, Z. (2011). Maslach tükenmişlik envanteri-öğrenci formu (MTE-ÖF)'nun Türkçe'ye uyarlaması: Geçerlik ve güvenirlik çalışması. Çukurova Üniversitesi Eğitim Fakültesi Dergisi, 40(1), 134-147.

Çokluk Bökeoğlu, Ö., \& Yılmaz, K. (2007). Üniversite öğrencilerinin fakülte yaşamının niteliğine ilişkin görüşlerinin çeşitli değişkenler açısından incelenmesi. Ankara Üniversitesi Eğitim Bilimleri Fakültesi Dergisi, 40(2), 179-204.

Deiaco, E., Hughes, A., \& McKelvey, M. (2012). Universities as strategic actors in the knowledge economy. Cambridge Journal of Economics, 36(3), 525-541. https://doi.org/10.1093/cje/bes024

Doğan, T., \& Çoban, A. (2009). Eğitim Fakültesi öğrencilerinin öğretmenlik mesleğine yönelik tutumları ile kaygı düzeyleri arasındaki ilişkinin incelenmesi. Ë̆itim ve Bilim Dergisi, 34(153), 157-168.

Doğan, T., Sarı, T., Kazak, M., Saya, P., \& Altıntaş, T. (2007). Başkent Üniversitesi öğrencilerinin problem alanlarının cinsiyet ve sınıf düzeyi değişkenlerine göre incelenmesi. Çağdaş Ĕ̆itim Dergisi, 32(347), 30-36. 
Dolunay, A. B. (2002). Keçiören ilçesi "Genel liseler ve teknik-ticaret-meslek liselerinde görevli öğretmenlerde tükenmişlik durumu" araştırması. Ankara Üniversitesi Tıp Fakültesi Mecmuası, 55(1), 51-62.

Dost, M. T. (2007). Üniversite öğrencilerinin yaşam doyumunun bazı değişkenlere göre incelenmesi. Pamukkale Üniversitesi Ĕ̈itim Fakültesi Dergisi, 2(22), 132-143.

Dursun, S., \& Karagün, E. (2012). Öğretmen adaylarının mesleki kaygı düzeylerinin incelenmesi: Kocaeli üniversitesi beden eğitimi ve spor yüksekokulu son sınıf öğrencileri üzerine bir araştırma. Kocaeli Üniversitesi Sosyal Bilimler Dergisi, 24, 93-112.

Epstein, J. L., \& McPartland, J. M. (1976). The concept and measurement of the quality of school life. American Educational Research Journal, 13(1), 15-30. https://doi.org/10.3102/00028312013001015

Erimez, C., \& Gizir, S. (2013). Eğitim Fakültesi öğrencilerinin öğretmenlik mesleğine yönelik tutumlarında fakültelerine yabancılaşmalarının rolü. Mersin Üniversitesi Ĕ̈itim Fakültesi Dergisi, 9(3), 13-26.

Freudenberger, H. J. (1974). Staff burnout. Journal of Social Issues, 30(1), 159-165. https://doi.org/10.1111/j.1540-4560.1974.tb00706.x

Frisby, B. N., Goodboy, A. K., \& Buckner, M. M. (2015). Students' instructional dissent and relationships with faculty members' burnout, commitment, satisfaction, and efficacy. Communication Education, 64(1), 65-82. https://doi.org/10.1080/03634523.2014.978794

Galbraith, C. S., \& Merrill, G. B. (2015). Academic performance and burnout: An efficient frontier analysis of resource use efficiency among employed university students. Journal of Further and Higher Education, 39(2), 255-277. https://doi.org/10.1080/0309877X.2013.858673

Goodboy, A., Martin, M., \& Johnson, Z. (2015). The relationships between workplace bullying by graduate faculty with graduate students' burnout and organizational citizenship behaviors. Communication Research Reports, 32(3), 272-280. https://doi.org/10.1080/08824096.2015.1052904

Gözler, A., Bozgeyikli, H., \& Avcı, A. (2017). Sınıf öğretmeni adaylarının başarı yönelimleri ile mesleki kaygı düzeylerinin incelenmesi. Abant İzzet Baysal Üniversitesi Eğitim Fakültesi Dergisi, 17(1), 189-211. https://doi.org/10.17240/aibuefd.2017.17.28551-304629

Gündüz, B., Çapri, B., \& Gökçakan, Z. (2012). Üniversite öğrencilerinin tükenmişlik düzeylerinin incelenmesi. Dicle Üniversitesi Ziya Gökalp Eğitim Fakültesi Dergisi, 19(2012), 38-55.

Gündüz, B., Çapri, B., \& Gökçakan, Z. (2013). Mesleki tükenmişlik, işle bütünleşme ve iş doyumu arasındaki ilişkilerin incelenmesi. Eğitim Bilimleri Araştırmaları Dergisi, 3(1), 29-49.

Hojat, M., Vergare, M., Isenberg, G., Cohen, M., \& Spandorfer, J. (2015). Underlying construct of empathy, optimism, and burnout in medical students. International Journal of Medical Education, 6, 12-16. https://doi.org/10.5116/ijme.54c3.60cd

Jackson, E. R., Shanafelt, T. D., Hasan, O., Satele, D. V., \& Dyrbye, L. N. (2016). Burnout and alcohol abuse/dependence among US medical students. Academic Medicine, 91(9), 1251-1256. https://doi.org/10.1097/ACM.0000000000001138

Kalaycı, H., \& Özdemir, M. (2013). Lise öğrencilerinin okul yaşamının niteliğine ilişkin algılarının okul bağl1lıkları üzerine etkisi. Gazi Üniversitesi Gazi Eğitim Fakültesi Dergisi, 33(2), 293-315.

Karatzias, A., Power, K. G., Flemming, J., Lennan, F., \& Swanson, V. (2002). The role of demographics, personality variables and school stress on predicting school satisfaction/dissatisfaction: Review of theliterature and research findings. Educational Psychology, 22(1), 34-50. https://doi.org/10.1080/01443410120101233

Kaya, Ş. D., \& Arı̈z, A. (2014). Ebe ve hemsire ögrencilerinde tükenmislik düzeyi ve etkileyen faktörler. Selçuk Üniversitesi Sosyal Bilimler Enstitüsü Dergisi, 31, 89-99.

Kırılmaz, A., Çelen, Ü., \& Sarp, N. (2003). İlköğretim'de çalışan bir öğretmen grubunda "tükenmişlik durumu" araştırması. Illkögretim-Online, 2(1), 2-9.

Kocaekși, S. (2016). The evaluation of burnout levels of sports sciences faculty students. Educational Research and Reviews, 11(4), 120-124. https://doi.org/10.5897/ERR2015.2600

Maslach, C. (2001). What have we learned about burnout and health? Psychology \& Health, 16(5), 607-611. https://doi.org/10.1080/08870440108405530 
Maslach, C., \& Leiter, M. P. (1997). The truth about burnout: How organizations cause personal stress and what to do about it. San Francisco, CA: Jossey-Bass.

Maslach, C., Schaufeli, W. B., \& Leiter, M. P. (2001). Job Burnout. Annual Reviews of Psychology, 52, 397-422. https://doi.org/10.1146/annurev.psych.52.1.397

Özdemir, M. (2012). Üniversite öğrencilerinin okul yaşamının niteliğine ilişkin algılarının cinsiyet ve fakülte değişkenlerine göre incelenmesi. Kuram ve Uygulamada Eğitim Yönetimi, 18(2), 225-242.

Özdemir, S., Kılınç, A. Ç., Öğdem, Z., \& Er, E. (2013). Eğitim fakültesi öğrencilerinin fakülte yaşamının niteliğine ilişskin memnuniyet düzeylerinin çeşitli değişsenler açısından incelenmesi (Vol. 3, No. 3, pp. 228-235).

Özoğlu, M. (2010). Türkiye'de öğretmen yetiştirme sisteminin sorunları. Seta Analiz, 17(26), 131-155.

Pines, A. M., \& Aronson, E. (1988). Career burnout: Causes and cures. New York: Free Press.

Rosenthal, B. S., \& Schreiner, A. C. (2000). Prevalence of psychological symptoms among undergraduate students in an ethnically diverse urban public college. Journal of American College Health, 49(1), 12-18. https://doi.org/10.1080/07448480009596277

Schaufeli, W. B., \& Bakker, A. B. (2004). Job demands, job resources and their relationship with burnout and engagement: A multi-sample study. Journal of Organizational Behavior, 25(3), 293-315. https://doi.org/10.1002/job.248

Schaufeli, W. B., Martinez, I., Marques-Pinto, A., Salanova, M., \& Bakker, A. (2002). Burnout and Engagement in University Students: A cross-national study. Journal of Cross Cultural Studies, 33(5), 464-481. https://doi.org/10.1177/0022022102033005003

Schwarzer, R. (2013). Self-related cognitions in anxiety and motivation. New Jersey: Lawrence Erlbaum Associates.

Stoliker, B. E., \& Lafreniere, K. D. (2015). The influence of perceived stress, loneliness, and learning burnout on university students' educational experience. College Student Journal, 49(1), 146-160.

Tabancalı, E., Çelik, K., \& Korumaz, M. (2016). Türkiye bağlamında hizmet öncesi öğretmenlerinin mesleki kaygı̈ düzeyleri. e-International Journal of Educational Research, 7(3), 63-73.

Thien, L. M., \& Razak, N. A. (2013). Academic coping, friendship quality, and student engagement associated with student quality of school life: A partial least square analysis. Social Indicators Research, 112(3), 679-708. https://doi.org/10.1007/s11205-012-0077-x

Tümkaya, S., Aybek, B., \& Çelik, M. (2007). An prediction of hopelessness and state-trait anxiety levels among teacher candidates before the KPSS exam. Kuram ve Uygulamada Egitim Bilimleri, 7(2), 967-974.

Yılmaz, K. (2007). İlköğretim okulu 6., 7. ve 8. sınıf öğrencilerinin okul yaşamının niteliğine ilişkin görüşleri. Kastamonu Eğitim Dergisi, 15(2), 485-490.

Yılmaz, K., \& Çokluk-Bökeoğlu, Ö. (2006). Fakülte yaşam niteliği ölçeği geçerlik ve güvenirlik çalışması. Türk Ĕgitim Bilimleri Dergisi, 4(2), 201-210.

\section{Copyrights}

Copyright for this article is retained by the author(s), with first publication rights granted to the journal.

This is an open-access article distributed under the terms and conditions of the Creative Commons Attribution license (http://creativecommons.org/licenses/by/4.0/). 